\title{
An Overview of Life Insurance ${ }^{1}$
}

\author{
Lisa Leslie and Martie Gillen²
}

\section{Purpose and Concepts}

The primary purpose for buying life insurance is to protect the people who depend on you. A life insurance policy can help to ensure your family's financial needs are met even after your untimely death. Life insurance can also provide a way to leave a cash gift to your spouse, children, grandchildren, or charities. Once you decide to buy a life insurance policy, you will have a few decisions to make. You will need to select among the different types of life insurance, decide on a dollar amount, and name your beneficiaries. In this publication, you will learn about the different types of life insurance and the ways to determine the amount of life insurance you may need.

A life insurance policy provides a cash payment to the beneficiary upon the death of an insured person. This payment is known as the death benefit. The insured is the person the policy is written for. The owner of the policy makes payments known as premiums to the insurance company. The insurance company pays the death benefit to the beneficiary of the policy if the insured person dies within the stated term.

There are two general kinds of life insurance-term or permanent life. Term life insurance pays a death benefit if the insured person dies during the term of the policy's coverage. Permanent insurance is meant to last a person's entire life (Leimberg, LeClair, Doyle, \& Robinson, 2006). Some common types of permanent life insurance are whole-life, universal-life, and variable universal-life.

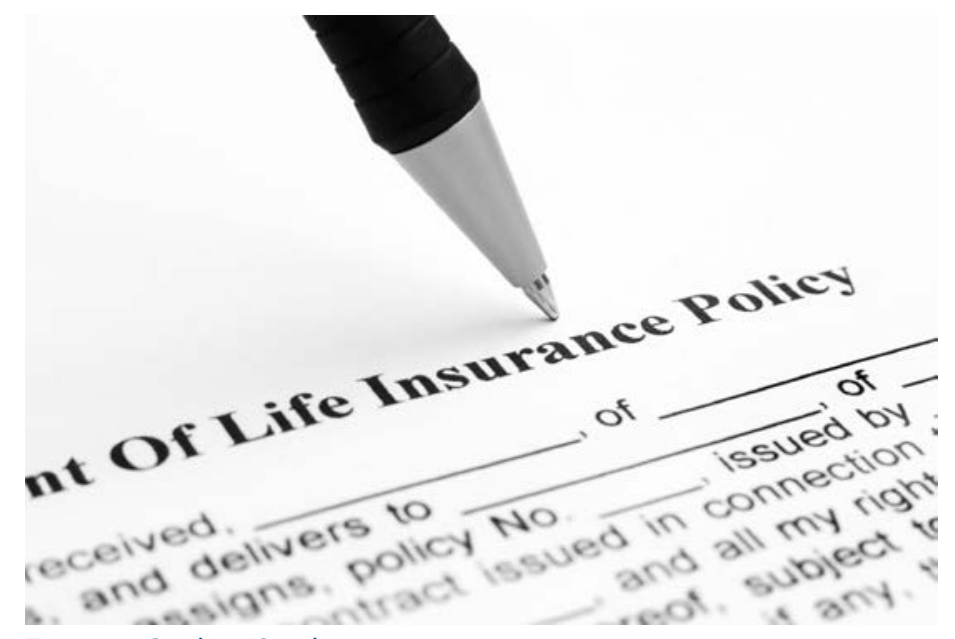

Figure 1. Credits: iStock

\section{Term Life Insurance}

Term life insurance provides coverage for a specific period of time (term) such as 10 years. Typically, term life insurance is the least expensive life insurance option. Depending on the type of term policy purchased, the premiums may increase with the age of the person insured. If the insured dies within the stated term, the insurance company pays the death benefit to the beneficiary. When the term ends, the insurance policy ends. Some companies only allow the term to last until a specified age, such as 70 or 80 years old. The owner may have the option of converting the policy to permanent insurance. This option may be limited by the owner's age or amount of time the term policy was held (Leimberg et al., 2006).

1. This document is FCS7254, one of a series of the Department of Family, Youth and Community Sciences, UF/IFAS Extension. Original publication date: October 2013. Visit the EDIS website at http://edis.ifas.ufl.edu.

2. Lisa Leslie, Extension agent, UF/IFAS Extension Hillsborough County; and Martie Gillen, assistant professor and Family and Consumer Economics for Older Adults specialist, Department of Family, Youth and Community Sciences; UF/IFAS Extension, Gainesville, FL 32611. 
The two types of term life insurance are annual renewable term and level premium term.

1. Annual renewable term life insurance provides you with one year of coverage at a time that you renew annually. Annual renewable term usually has the lowest annual premium to start, but the premium rises as you age. An annual renewable term policy typically guarantees the ability to reinsure for a period of years, often 10-30 years, depending on the insured's age.

\section{Level premium term life insurance provides you with} coverage for a specific multiyear period (e.g., 5, 10, or 20 years). The longest terms are usually 30 years. Level premium term lets you lock in the premium for the specified term; the annual premium is guaranteed never to change, from the first year to the last.

“Group” term life insurance may be offered through your employer. Group policies typically cost less than an individual policy, and the company may pay the premium to insure you. The policy usually remains in effect while you work for the employer and usually ends when your employment ends. Check with your human resources department to determine if you have this benefit and the benefit amount or the amount you are eligible for. You may be able to purchase additional life insurance though your employer's group term life insurance.

\section{Permanent Life Insurance}

The three main types of permanent life insurance are 1) whole-life insurance, 2) universal-life insurance, and 3) variable universal-life insurance.

1. Whole-life insurance (cash value) generally has more expensive premiums than term life insurance. The premiums are more expensive because the goal is to cover the cost of the insurance and build up a cash-value reserve. The cash value is the difference between the premium and the actual cost of the insurance. The cash-value amount is maintained in a separate account by the insurance company and can be used to help the policy owner pay the premiums (Hayhoe \& Smith, 2005a). As mentioned above, whole-life policies are meant to last the owner's lifetime. In advanced age, purchasing or renewing a term policy can be cost-prohibitive. However, with a whole-life policy, the cash value built from the higher premiums throughout the insured's life means they will not have a cost-prohibitive increase in premiums when they are older.
The policy owner may take a loan by borrowing against the cash value or receive it if the policy is surrendered (canceled). It is important to note that there may be charges (interest and/or fees) associated with borrowing against the cash value or canceling the policy before the death of the insured. At death, the beneficiary only receives the death benefit, not the death benefit and the cash value (Hayhoe \& Smith, 2005a).

2. Universal-life insurance is similar to whole-life in that it provides coverage throughout the policyholder's life and builds cash value that keeps premiums from becoming cost-prohibitive as the owner ages. It is different from whole-life because policy owners have flexibility in how they pay premiums and can change their policy's death benefits. A universal-life policy also provides detailed disclosure about the policy's expenses, mortality charges, and interest rates (Leimberg et al., 2006).

After the first policy year, the policy owner can change how he or she funds the policy account within a minimum and maximum limit. There is a minimum amount that must be in the cash-value account to keep the policy in force and provide a death benefit. However, if the policy owner only pays the minimum, it only covers the cost of the insurance portion of the coverage and does not build cash value. In this case, the consumer may be better off with term-life insurance. A policy owner may decide to fund up to the maximum amount to get more tax-deferred growth.

The policy owner has a choice of two different death benefits, usually called Option A and Option B. Option $A$ has a level death benefit until the policy owner reaches an advanced age. In Option B, the death benefit is a fixed amount plus the cash-value amount. So with Option $\mathrm{B}$, the death benefit can increase over time as the cash value grows, but the mortality charge also increases as the policy owner ages (the mortality charge is the cost of life insurance based on the insured's risk classification and age, as well as the policy amount). For Option A, the death benefit stays the same regardless of the cash value, and the mortality charge may increase more slowly or decrease over time (Hayhoe \& Smith, 2005c).

Universal-life policies allow the policy owner to withdraw money from the account. Unlike whole-life policies, these withdrawals are not considered loans, so interest is not charged (Hayhoe \& Smith, 2005c). However, enough of the cash-value amount must be left to cover the cost of the policy. 
3. Variable universal-life insurance is similar to whole-life and universal-life in that it provides a death benefit for a certain premium amount. It is different because the policy owner also funds sub-accounts that contain more risky investments such as stocks. The policy owner can diversify allocations in the sub-accounts to include a variety of stocks and bonds. In this way, it combines an insurance product with a more risky investment product. The policy owner may end up with a policy that pays more than the death benefit or one that costs more because of investment losses (Hayhoe \& Smith, 2005d).

\section{Tax Considerations}

Insurance products do come with tax benefits. Death benefits paid to a beneficiary are not taxable. In addition, earnings on the money held in the savings or investment portion of life insurance accounts grow tax deferred.

\section{Evaluate Carefully}

You should carefully evaluate your life insurance needs. Proceed cautiously before using an insurance product as an investment product. Insurance products may come with higher fees and commissions that make them less costeffective than other investment products. When evaluating the tax benefits, realize that other types of accounts, such as college-savings accounts and retirement accounts, also offer tax-deferred growth.

Factors other than age also influence the cost of life insurance. For example, smoking will likely increase the cost of your life insurance policy.

Your health plays a big part in the price of life insurance. When you buy a policy, you will have to answer questions about your health and other activities. For example, your hobbies may increase the cost of your life insurance. If your hobbies present a significant level of risk, the insurance company may take that into account for your policy. As examples, if you enjoy rock climbing, mountaineering, car racing, or skydiving, that might impact the cost of your life insurance.

Also, be sure you know what causes the policy to be invalid. For example, death by suicide or skydiving may make a policy invalid. Read the fine print carefully because policies vary.

\section{How Much Insurance Do You}

\section{Need?}

Do you have enough life insurance to provide for your family if something happened to you? Protecting your family is important but you also need to make sure you're not spending money on insurance that could be used for other needs. The key is to find the right balance. The amount of life insurance you need depends on your situation.

Life insurance needs typically fluctuate throughout your life. For example, if you have dependent children, you will have more life insurance than a single person without children. Life insurance is important for stay-at-home moms, because you would have pay for that service if something happened to mom. Divorced couples should consider carrying a policy on the ex-spouse if he or she depends on that person for child support.

Consider the following questions when estimating your life insurance needs:

- How much will my family need to meet immediate obligations?

- Immediate obligations include funeral expenses, etc., and outstanding debt such as a mortgage.

- How much will my family need to sustain the household?

- Consider your current annual income and your spouse's income.

- This may include long-term expenses such as college for your children.

- When determining this amount, consider available resources such as Social Security survivor benefits, investment assets, retirement accounts (i.e., 401(k)), and any existing life insurance.

\section{Verify Before You Buy!}

Florida residents should make sure that a company is licensed in Florida. You can also check the financial strength and stability of a company using a rating service such as Moody's or A.M. Best.

Start your research by using the links on the Florida Department of Financial Services website: http://www. myfloridacfo.com/division/consumers/purchasinginsurance/verifybeforeyoubuy.htm. 


\section{Remember to Update Your Policy}

A change in your financial situation or a birth, death, marriage, or divorce in your family could require you to update your beneficiaries or the amount of life insurance you need.

\section{References}

Hayhoe, C. R., \& Smith, M. (2005a). Life insurance: The different types of policies. Blacksburg, VA: Virginia Cooperative Extension. Retrieved from http://pubs.ext. vt.edu/354/354-143/354-143.html

Hayhoe, C. R., \& Smith, M. (2005b). Life insurance: Whole-life insurance. Blacksburg, VA: Virginia Cooperative Extension. Retrieved from http://pubs.ext. vt.edu/354/354-145/354-145.html

Hayhoe, C. R., \& Smith, M. (2005c). Life insurance: Universal-life insurance. Blacksburg, VA: Virginia Cooperative Extension. Retrieved from http://pubs.ext. vt.edu/354/354-146/354-146.html

Hayhoe, C. R., \& Smith, M. (2005d). Life insurance: Variable universal-life insurance. Blacksburg, VA: Virginia Cooperative Extension. Retrieved from http://pubs.ext. vt.edu/354/354-147/354-147.html

Leimberg, S. R., LeClair, R. T., Doyle, R. J., \& Robinson T. R. (2006). Investment planning. Cincinnati, OH: National Underwriter Company. 